IJTC

Ilomata International Journal of Tax \& Accounting

P-ISSN: 2714-9838; E-ISSN: 2714-9846

Vol. 1 No. 1 October 2019 page:26-34

https://www.ilomata.org/index.php/ijtc

\title{
Analysis on Exchange of Information (EOI) to Increase the Quality of Investigation on Beneficial Owner Dispute (BO) According to Verdict of Tax Court from 2013 to 2015 in Directorate of Objection and Appeal
}

\author{
Rudi Hartasetiadi ${ }^{1}$, Machfud Sidik ${ }^{2}$ \\ Master of Administration Science, Institute of Social Science and \\ Management STIAMI, Jakarta \\ Correspondence: rudi.hartasetiadi@gmail.com
}

Submitted: 6 August 2019.

Revised: 23 August, 20

Sept 2019.

Published: 30 October 2019.

\begin{abstract}
Based on the research of Taxpayer who has done a cross-jurisdiction transaction, known that taxpayers have done several transactions with Tax Heaven country corporation. One of the goals of the transaction is to take advantage of the gap on Tax Treaty /P3B to achieve treaty benefit. Tax auditing is a tool to ensure that the party who received the income in treaty partner countries is the Beneficial Owner (BO) thus there will be no misused of P3B/treaty abuse. Exchange of Information (EOI) is a tool for gaining information, evidence, and/or explanation to gain a conviction of who are truly received the benefit. Considering the importance of quality of investigation to appeal in Tax Court, it is interesting to review about the usage of Exchange of Information (EOI) to increase the quality of tax investigation of $\mathrm{BO}$ dispute, in this case, Directorate of Objection and Appeal. In arranging this research, researchers used a qualitative approach considering the focus of research is the usage of EOI on the investigation which has many factors and not monocausal means there is no one single cause from social reality. This research intends to know the use of EOI in increasing quality of tax auditing if it is reviewed from Tax Court verdict, supporting entities and the efforts which support the use of EOI in increasing the investigation of beneficial owner dispute. The result of this research explains that EOI usage to increase the quality of tax auditing of beneficial owner dispute has not been maximal or still low if it is assessed from the Tax Court verdict which DGT's percentage of losing verdict is higher than winning verdict. Factors that contributes the usage of EOI in increasing the quality of examination is human resource, which have good quality and quantity of examiner, competent database system and good obedience of taxpayers, good technique of examining, clear and not
\end{abstract}


Analysis on Exchange of Information (EOI) to Increase the Quality of Investigation on Beneficial Owner Dispute (BO) According to Verdict of Tax Court from 2013 to 2015 in Directorate of Objection and Appeal

Hartasetiadi, Sidik

misinterpreted rules of $\mathrm{BO}$ and EOI, good cooperation between partner country, good coordination and support in internal unit of DJP. Meanwhile, entities that could obstruct usage of EOI in increasing investigation quality of beneficial owner dispute is the human resource, which means that investigation quality that has to be increased and quantity of the investigators that are not sufficient. Directorate General of Taxes not yet has competent database, low obedience of taxpayers, absence of rules about Investigation Technique about beneficial owner dispute, limited period of investigation, different interpretations from judges, inchoate and unclear information in EOI, answers of EOI request that has not fulfilled by cooperating countries and unclear and weak rules about beneficial owner Keyword: exchange of information, EOI, beneficial owner, BO

\section{INTRODUCTION}

In examining the obedience of taxpayers about the implementation of taxation law and regulation, the Directorate General of Taxation has the right to do an investigation. This is done to know the truth about transactional recording and the accuracy of financial statements that had arranged from accounting. Therefore, an investigation is necessary. If the taxpayer investigation stated that the amount of loss, tax, and collection or discount is not supposed to be, then the taxpayer could submit the objection only to Directorate General of Taxation, and if the objection is not satisfying the taxpayer can appeal through Tax Court.

Table 1. Number of Dispute in Tax court on 2011-2016

\begin{tabular}{|c|c|c|c|c|c|c|}
\hline \multirow{2}{*}{$\begin{array}{l}\mathbf{N} \\
\mathbf{o}\end{array}$} & \multirow{2}{*}{$\begin{array}{l}\text { Appellee / } \\
\text { Defendant }\end{array}$} & \multicolumn{5}{|c|}{ Numbers of Document Received } \\
\hline & & 2012 & 2013 & 2014 & 2015 & 2016 \\
\hline $\mathbf{1}$ & $\begin{array}{l}\text { Directorate } \\
\text { General of Tax }\end{array}$ & 5.114 & 5.188 & 7.289 & 7.454 & 7.080 \\
\hline 2 & $\begin{array}{l}\text { Directorate } \\
\text { General of } \\
\text { Customs and } \\
\text { Excise }\end{array}$ & 1.754 & 2.749 & 3.016 & 4.068 & 3.023 \\
\hline 3 & $\begin{array}{l}\text { Regional } \\
\text { Government }\end{array}$ & 485 & 462 & 561 & 964 & 50 \\
\hline & Total & 7.353 & 8.399 & 10.866 & 12.486 & 10.153 \\
\hline
\end{tabular}

Source: www.setpp.kemenkeu.go.id

Considering the importance of Exchange of Information (EOI) to determine the strength of a beneficial owner dispute which going to be put 
Analysis on Exchange of Information (EOI) to Increase the Quality of Investigation on Beneficial Owner Dispute (BO) According to Verdict of Tax Court from 2013 to 2015 in Directorate of Objection and Appeal

Hartasetiadi, Sidik

on trial in Tax Court, analysis of EOI usage is an interesting thing to do to increase the investigation quality on Beneficial Owner dispute (Bacchetta \& Espinosa, 1995). The term Beneficial Owner has been introduced in the Law of Income Tax, as the party who received the actual benefit from the income that has been received from a sourcing country (Bacchetta \& Espinosa, 2000).

Taxpayer behavior in reality, with forming a scheme which done to get a facility, for example, a decrease of tax discount that has been provided by a tax treaty, by a tax subject which has no right to get the facility (Giuliodori \& Beetsma, 2008). This is caused by using articles in the tax treaty that are not suitable for the purpose and objectives of the tax treaty (Gallemore \& Labro, 2015). To prove the true receiver of the benefit, it is not sufficient to prove just based on internal data of Directorate General of Tax or any data from the taxpayer, because it involves the information of receiver entities in treaty cooperating country. Therefore, the EOI procedure has an important role to find the necessary information to prove the benefit receiver of the income that has received.

This research on EOI usage in increasing the quality of investigation about beneficial owner dispute is using the verdict of tax court in Directorate of Objection and Appeal, Main Office Directorate General of Taxes. The verdict is the Verdict of Tax Court of the beneficial owner that has been resolved in 2013 to 2015.

\section{Table 2. Numbers of Dispute Settlement of Beneficial Owner in Tax Court 2013 to 2015

No Types of Verdict $2013 \quad 2014 \quad 2015 \quad$ Grand \\ Total

\begin{tabular}{llrrrr} 
1 & Partially Granted & 0 & 1 & 1 & 2 \\
\hline $\mathbf{2}$ & Fully Granted & 19 & 38 & 24 & 81 \\
\hline $\mathbf{3}$ & Declined Application & 0 & 6 & 0 & 6 \\
\hline Jumlah & 19 & 45 & 25 & 89
\end{tabular}

Source: Directorate of Objection and Appeal

As seen from the table above, the verdict of the Tax Court about beneficial owner disputes from 2013 until 2015, there is more granted appeal than to hold the correction. This indicates the low quality of tax examination on beneficial owner disputes. More likely, a country will have a loss if a beneficial owner does not take into consideration. Because for payment of interest, dividend and royalty to another country, should be decreased from $20 \%$ into $10 \%$ or $0 \%$. 
Analysis on Exchange of Information (EOI) to Increase the Quality of Investigation on Beneficial Owner Dispute (BO) According to Verdict of Tax Court from 2013 to 2015 in Directorate of Objection and Appeal

Hartasetiadi, Sidik

As seen from the table above, the verdict of the Tax Court about beneficial owner disputes from 2013 until 2015, there is more granted appeal than to hold the correction. This indicates the low quality of tax examination on beneficial owner disputes. More likely, a country will have a loss if a beneficial owner does not take into consideration. Because for payment of interest, dividend and royalty to another country, should be decreased from $20 \%$ into $10 \%$ or $0 \%$.

\section{METHOD}

Neuman differentiates the research approach into qualitative and quantitative approaches (Neuman, 2011). In arranging this research, the researchers used a qualitative approach considering the focus of this research is the quality of examination which has many factors and monocausal, meaning that there is no one single cause of social reality. The other reason why the researchers used qualitative approach is that the research cannot be done experimentally as stated by Marshall and Rossman (1999:46) ".... research cannot be done experimentally for practical or ethical reasons"(Marshall \& Rossman, 1999). Quality of investigation is the tipping point of law enforcement in the General Directorate of Tax. Consequently, qualitative approach is considered could determine the obedience level of taxpayers because the researchers themselves interviewed without any third parties.

\section{RESULT AND DISCUSSION}

Community development effort through the self-assessment system needs to be followed by monitoring to actualize the goal of tax wisdom. Consequently, the tax auditors in doing their monitoring duty, need to be supported by supporting factors, one of them is to imply strategical action to increase the amount of taxpayers' obedience. Because the main goal of tax auditing is to increase tax compliance through law enforcement efforts to increase the tax revenue.

Related to the investigation of beneficial owner dispute basically to ensure that foreign taxpayers deserve rate discount from $20 \%$ to $10 \%$ or $0 \%$ on interest, dividend and royalty income. One of the monitoring forms on discount/collection reporting done by taxpayers about beneficial owner dispute is Director General of Tax Regulation number 61/PJ/2009 and Director General of Tax Regulation number 62/PJ/2009. Those regulations 
Analysis on Exchange of Information (EOI) to Increase the Quality of Investigation on Beneficial Owner Dispute (BO) According to Verdict of Tax Court from 2013 to 2015 in Directorate of Objection and Appeal

Hartasetiadi, Sidik

are domestic antitreaty abuse rules that can be implied and not contrary to other regulations in the Tax Treaty (P3B).

Quality of tax investigation on beneficial owner dispute, reviewed from the verdict of Tax Court which percentage of loss is bigger than winning is still low. Usage on Exchange of Information in the investigation is expected to increase the quality of investigation on the Beneficial Owner dispute. With enhancement on the quality of investigation, it is expected to decrease the amount of tax dispute in objection level, and in the end increased the taxpayer obedience in fulfilling taxation duty (Bucovetsky, Marchand, \& Pestieau, 1998; Eggert \& Kolmar, 2004).

That in Exchange of Information implementation, there are principles that have to be watched out for as stated on other tax regulation, inter alia, Minister of Finance Regulation No. 39/PMK.03/2017 about information exchanged, obligation to keep it confidential, possible condition to conduce EOI, conditions that have to be fulfilled before doing EOI.

Among other principles that have to be watched out, EOI implementation is strongly related to the human role, in this case, Tax Auditor. In monitoring Beneficial Owner case, is very important for tax auditors to understand the case that they are working on and regulations about thus the monitoring implementation can determine a precise investigating technique such as types of data that is used to plan EOI, choosing information of which going to be asked, understanding regulations, domestic, cross-country, international, etc (Markis, 2003).

According to interview results with informants from internal, practitioner, consultant, or academician, entities that supports the usage of Exchange of Information in increasing the quality of investigation on Beneficial Owner dispute is human resource, i.e, quantity, and quality of investigators, competent database, auditing technique, periods of auditing, regulations on beneficial owner, good obedience of taxpayer, cooperation between Treaty Partner countries, and Coordination between DJP units. Meanwhile, the obstacles that can be found in utilizing Exchange of Information in order to increase the quality of tax auditing on beneficial owner disputes are human resources, i.e, quality and quantity of auditor that still considered less competent, Directorate General of Taxation has not had competent database, there are not yet any regulations about auditing technique about beneficial owner disputes, limited period, low obedience of taxpayers, different interpretations between judges about beneficial owner 
Analysis on Exchange of Information (EOI) to Increase the Quality of Investigation on Beneficial Owner Dispute (BO) According to Verdict of Tax Court from 2013 to 2015 in Directorate of Objection and Appeal

Hartasetiadi, Sidik

provisions, incomplete information of EOI and answer that has not yet fulfilled by partner countries.

According to interview results with informants from internal, practitioner, consultant, and taxpayers, efforts that could be done to increase the investigation quality on beneficial owner dispute are to increase the quality of investigator human resource, forming a competent database system, increase the knowledge awareness of taxpayers, arranging regulation about direction of investigation technique on beneficial owner dispute, increase the length of investigation period, arranging a clear law about beneficial owner in determining which has more authority in Indonesia's law and regulation-Minister of Finance Regulation, increasing the cooperation with Tax Treaty partner countries to harmonize the rules about beneficial owner and maintain the coordination among internal unit of Directorate General of Tax.

\section{CONCLUSION}

According to result about analysis of the exchange of information (EOI) to increase the quality of investigation on beneficial owner dispute (BO) according to the verdict of Tax Court from 2013 to 2015 in Directorate of Objection and Appeal, Main Office of Directorate General of Tax can be concluded along these lines:

1. EOI usage in tax auditing about $\mathrm{BO}$ has a significant role in increasing the quality of investigation. Information in EOI can be used as evidence in conducting fiscal correction. Usage of EOI procedure in the investigation has to consider the principles that have been set in tax regulation, i.a, information that could be exchanged, obligation to keep it confidential, possible condition to conduct EOI, conditions that should be fulfilled before conducting EOI. Implementation of EOI has a strong relationship with the human role, in this case, the tax auditor. It is important for Tax Auditor in investigating Beneficial Owner dispute, to understand the case and related regulation so that in investigating there is precise investigation technique such as types of necessary, planning the EOI, choosing information that probably will be requested, understanding the regulation-domestic, cross country, international, etc. Therefore, in investigating, understanding and experience are necessary for investigators about the importance of EOI and regulation of $\mathrm{BO}$ itself. Coordination among internal units in Directorate General of Tax who are in charge of EOI and support from 
Analysis on Exchange of Information (EOI) to Increase the Quality of Investigation on Beneficial Owner Dispute (BO) According to Verdict of Tax Court from 2013 to 2015 in Directorate of Objection and Appeal

\section{Hartasetiadi, Sidik}

institution in form of, i.a, courses, training, or supervision, are important for supporting EOI implementation. Tax audit quality in beneficial owner dispute is still low, reviewed from the verdict of Tax Court where the losing percentage of Directorate General of Tax is higher than winning percentage.

2. According to the result, known the quality level of tax auditing can be reviewed from many angles, such as weakness of data, low competence of auditor, the period of investigation, and unbinding regulation. Supporting entities that can back up the usage of EOI in increasing the quality of tax auditing on BO dispute is human resource, those are good quality and quantity of adequate investigator, competent database, obedience of taxpayer, appropriate investigation technique, and clear and unambiguous regulation of $\mathrm{BO}$ and EOI, good cooperation between partner countries, solid coordination and support around DGT internal unit. Entities that obstruct EOI usage in increasing the quality of investigation on beneficial owner dispute are human resource, those are quality of investigator that needs to be improved, inadequate quantity of investigator, incompetent database of DGP, limited period of investigation, judge's misinterpretation, insufficient and unclear information in EOI, answer of EOI request that has not immediately fulfilled by government, and ambiguous and undependable BO regulation..

After an in-depth interview to the informants from judges of Tax Court, revenue officer, practitioner, and academician, the results of this research are:

1. EOI can increase the quality of the investigation. Following Taxation General Provisions Law article 29 section (2), the opinion and conclusion of the investigator shall be based on strong and coherent evidence also based on provisions of the taxation law and regulation.

2. Quality of tax auditing on beneficial owner dispute is still low of assessed from tax court verdict where the percentage of DGT losing is bigger than winning.

3. An effective method in conducting EOI procedure is EOI by request or EOI which conducted through request.

4. The main elements of EOI are the demand of information alongside the evidence about BO's transaction and adjusted with applicable tax provisions. 
Analysis on Exchange of Information (EOI) to Increase the Quality of Investigation on Beneficial Owner Dispute (BO) According to Verdict of Tax Court from 2013 to 2015 in Directorate of Objection and Appeal

Hartasetiadi, Sidik

5. Related to tax provision that arranged Beneficiary Owner criteria, especially Director General of Tax Regulation number PER-61/PJ/2009 stdd PER24/PJ/2010 and PER-62/PJ/2009 stdd PER-25/PJ/2010 have clearly stated, but there are still some conditions about BO that make possible to different interpretation that could provoke the dispute with the taxpayer.

6. In conducting EOI, DGT does not need to ask the Competent Authority for determining the party that receives the benefit (BO) from the income received from Indonesia. Considering now every citizen has the right to issue the provision about the definition and determination of Foreign Taxpayer (FT) as a beneficial owner. Under OECD Model, UN Model and Treaty Indonesia and Contracting State highlighted that interpretation on terminology that used in the Double Tax Treaty (International Meaning) should be interpreted based on the definition in which regulated on domestic law (Domestic Meaning) from the country that holds the treaty.

7. Director General of Tax Regulation number PER-61/PJ./2009 about the administrative procedure as the clue for discounters to get treaty benefits. If the discounter can make use of the treaty, then discounter can get as much as a treaty (relief of source) if taxpayer complaint can be done a refund effort (relief at refund). Director General of Tax Regulation number PER-62/PJ./2009 for the prevention of treaty misuse, a treaty for expediting the service and good flow is not only for treaty benefit.

8. Form DGT-1 and DGT-2 in PER-61/PJ/2009 and beneficial owner criteria in PER-62/PJ/2009 have not sufficiently proved that the party who received foreign income is the beneficial owner. Beneficial owner examining can be used with the approach of misuse of tax treaty (treaty abuse). To examine this treaty abuse, it is done by conducting an exchange of information. Based on result data of that exchange of information, the beneficial owner is analyzed, a company is not a beneficial owner if fulfill the conditions:

a. The company was established in tax treaty Cooperating State or the structure setting / transaction scheme was not only aimed for tax treaty utilization;

b. Business activity is managed by own management which has sufficient authority to do transactions

c. The company has employees ;

d. Have business activity or active business;

33 | Ilomata International Journal of Tax \& Accounting Vol. 1 No. 1 Oct2019 
Analysis on Exchange of Information (EOI) to Increase the Quality of Investigation on Beneficial Owner Dispute (BO) According to Verdict of Tax Court from 2013 to 2015 in Directorate of Objection and Appeal Hartasetiadi, Sidik

e. Income from Indonesia is in tax debt in received country; and

f. Not using $50 \%$ (fifty percent) of the total income to fulfill the liability to any other party in form of: interest, royalty, and any other honorarium.

9. Director General of Tax Regulation number 61/PJ./2009 and Director General of Tax Regulation number 62/PJ./2009 about the anticipation of treaty abuse that has been changed into PER-25/PJ/2010, in this case, it is a form of domestic anti-treaty abuse rules that could be applied with provisions from tax treaty. The weakness of Director General of Tax Regulation number PER-61/PJ./2009 and PER-61/PJ./2009 is the legal force because Director General of Tax Regulation is not included in the hierarchy of law and regulations and not mandated by law.

10. The related case of beneficial owner in the world that can be used as references such as Indofood (UK), Prevost 2006 (Canada) and V. SA Sweden (2001)

11. Entities that supports the EOI usage in increasing the quality of tax auditing on beneficial owner dispute are good quality and quantity of investigator, competent database, obedience of taxpayer, appropriate investigation technique, and clear and unambiguous regulation of $\mathrm{BO}$ and EOI, good cooperation between cooperating countries, solid coordination and support around DGT internal unit.

12. Entities that obstruct EOI usage to increase the quality of investigation of beneficial owner dispute are human resource, those are inadequate quality and quantity of investigator, incompetent database of DGP, limited period of investigation, weak regulations about beneficial owner, judge's misinterpretation, insufficient and unclear information in EOI, answer of EOI request that has not immediately fulfilled by cooperating government.

13. Efforts that could be done to support EOI usage in increasing the quality of tax auditing and beneficial owner dispute are to increase the quality of investigator human resource, forming a competent database system, increase the knowledge awareness of taxpayers, arranging regulation about direction of investigation technique on beneficial owner dispute, adding length of investigation period, arranging a clear law about beneficial owner in determining which has more authority in Indonesia's law and regulation-Minister of Finance Regulation, increasing the cooperation with Tax Treaty cooperating countries or OECD and harmonizing the coordination among internal DGT units (Michalos, 2019)

34 | Ilomata International Journal of Tax \& Accounting

Vol. 1 No. 1 Oct2019 
Analysis on Exchange of Information (EOI) to Increase the Quality of Investigation on Beneficial Owner Dispute (BO) According to Verdict of Tax Court from 2013 to 2015 in Directorate of Objection and Appeal Hartasetiadi, Sidik

Suggestions that the researchers could give related to the result of research are among these lines:

1. Investigator Human Resource Policies

a. Increasing in human resource capacity through programs: socialization, sharing knowledge, seminars, crash courses, in-house training about the theory and EOI implementation or international taxation theory especially about beneficial owner dispute from International Directorate of Tax. Increasing in the capacity of human resource is done thoroughly, considering there are not any specialization in investigators that only handling beneficial owner investigation.

b. Forming the International Taxation team but still refers to international taxation provision that applicable and other country provisions that applied technical guidance or assistance to the functional including truth investigator and appeal officers about EOI usage and beneficial owner disputes.

c. Improvement in mutation pattern with looking at specialization note owned by each investigator

2. Forming competent database with:

a. Maximizing the exchange of information with tax treaty cooperating countries' taxation authority. Hence, complete data from Exchange of Information can be obtained in a short time i.a, financial report, deed of incorporation, cooperation income tax return, list of directors and commissioners, and photos of cooperation in cooperating countries. The database is also necessary for spontaneous or automatic EOI with the database which Indonesia have can do spontaneous and automatic EOI so that cooperating countries are delightfully expected to do the same treatment and give the answers on every requested information in EOI;

b. Synergy and cooperation with the related institution on database forming;

c. Forming an integrated database in Tax Authority in Indonesia about the cross-border transaction which occurs to the Indonesian Taxpayer.

3. Investigation policies: 
Analysis on Exchange of Information (EOI) to Increase the Quality of Investigation on Beneficial Owner Dispute (BO) According to Verdict of Tax Court from 2013 to 2015 in Directorate of Objection and Appeal Hartasetiadi, Sidik

a. Making provisions about investigation technique guidance on beneficial owner disputes. Thus, the technique can be used as investigating reverence in order to investigating beneficial owner dispute related especially how to take advantage or investigation period with EOI usage about getting EOI answer from Competent Authority (CA) of Cooperating States or possibility about evidence information development or explanation that requires EOI with previous cooperating country CA, or even other countries CA.

b. Extended period of investigation. Investigation period in special criteria is 4 months, with that time, investigators found it hard to do investigations because the EOI data has not yet received. For comparison, in India only for $\mathrm{BO}$ investigation that requires EOI, the period is set for 2 years.

4. Policies about BO with arranging new clear and unambiguous regulations about beneficial owner for taxpayer and investigator in determining beneficial owner which has more authority in Indonesia's law and regulation, in this case, Minister of Finance.

5. DGT organization policies

a. Increasing the cooperation between tax treaty countries and OECD especially in harmonizing law about the beneficial owner.

b. Maintain strong coordination among internal units of DGT.

6. Increasing the obedience and knowledge on taxpayer on beneficial owner dispute through:

a. Socialization to taxpayer to increase the obedience about the investigation in beneficial owner dispute, for example, deliverance and filing of Certificate of Domicile, data deliverance or document, and definition.

b. Routine socialization on regulations about the beneficial owner to the taxpayer that conducts a transaction with foreign countries.

\section{REFERENCE}

Bacchetta, P., \& Espinosa, M. P. (1995). Information sharing and tax competition among governments. Journal of International Economics, 39(1-2), 103-121. https://doi.org/10.1016/0022-1996(94)01356-W

Bacchetta, P., \& Espinosa, M. P. (2000). Exchange-of-Information Clauses in International Tax Treaties. International Tax and Public Finance, 7(3), 
Analysis on Exchange of Information (EOI) to Increase the Quality of Investigation on Beneficial Owner Dispute (BO) According to Verdict of Tax Court from 2013 to 2015 in Directorate of Objection and Appeal

Hartasetiadi, Sidik 275-293. https://doi.org/10.1023/A:1008753629558

Bucovetsky, S., Marchand, M., \& Pestieau, P. (1998). Tax Competition and Revelation of Preferences for Public Expenditure. Journal of Urban Economics, 44(3), 367-390. https://doi.org/10.1006/juec.1997.2075

Eggert, W., \& Kolmar, M. (2004). The Taxation of Financial Capital under Asymmetric Information and the Tax-competition Paradox. Scandinavian Journal of Economics, 106(1), 83-106. https://doi.org/10.1111/j.0347-0520.2004.t01-1-00349.x

Gallemore, J., \& Labro, E. (2015). The importance of the internal information environment for tax avoidance. Journal of Accounting and Economics, 60(1), 149-167. https://doi.org/10.1016/j.jacceco.2014.09.005

Giuliodori, M., \& Beetsma, R. (2008). On the relationship between fiscal plans in the European Union: An empirical analysis based on real-time data. Journal of Comparative Economics, 36(2), 221-242. https://doi.org/ 10.1016/j.jce.2007.11.002

Makris, M. (2003). International Tax Competition: There is No Need for Cooperation in Information Sharing. Review of International Economics, 11(3), 555-567. https://doi.org/10.1111/1467-9396.00402

Marshall, C., \& Rossman, G. B. (1999). Designing qualitative research. 3rd edition. Thousand Oaks.

Michalos, A. C. (2019). Global Forum on Transparency and Exchange of Information for Tax Purposes. In Encyclopedia of Business and Professional Ethics (pp. 1-3). https://doi.org/10.1007/978-3-319-235141 1162-1

Neuman, W. L. (2011). Social Research Methods: Qualitative and Quantitative Approaches. In Pearson Education. 